えられる。

今, 試料 $2.5 \mathrm{~g}$ を容 $200 \mathrm{cc}$ のビーカーに科取し, 水 $100 \mathrm{cc}$ を加え， N/10-NaOH 溶液で $\mathrm{pH}$ を 2 6 調節した後 $250 \mathrm{cc}$ メスフラスコに移し入れ振とらした場合，その抽出時の $\mathrm{pH}$ と $\mathrm{P}_{2} \mathrm{O}_{5}$ 定量結果の関係を図示すれば図 3 のごとくになる。

図３によって明らかなと招り，W.P 測定結果は抽出液の $\mathrm{pH}$ によって変化する。 $\mathrm{pH} 4$ 以上で性 $\mathrm{CaHPO}_{4}$ が沈股して, 定量 結果は過少となる特とれがあるから，W.P の定量に際しては上 記操作によって，pH 3.5〜4 と調邻した後振とうを行えばよい。

S.P の定量法としては試料 $2.5 \mathrm{~g}$ を $250 \mathrm{cc}$ メスフラスコにと り，ペーテルマン氏夜 $200 \mathrm{cc}$ を加え，30 分閒振と5を行なった 後，60 $\mathrm{C}$ に保った湯せん上で加温抽出し，常法により定量すれ ばよい。
上記改良法によって得られた結果と公定法による結果の比㜞を 表 1 に示す（試料は 8-8-5 化成肥料)。

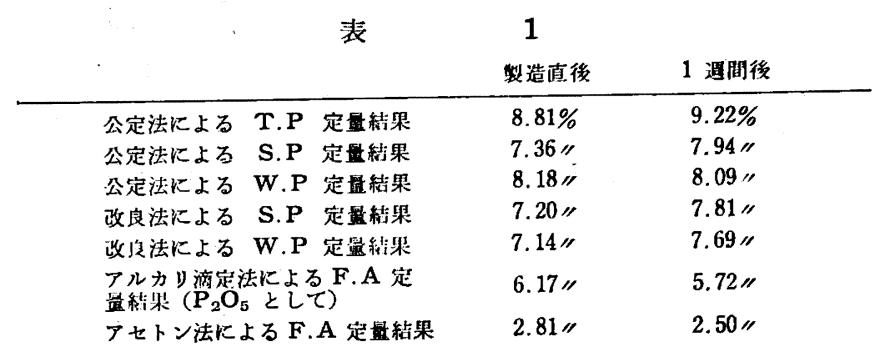

（昭和 30 年 4 月，日化第 8 年会講演）

終りに発表を許可された株式会社多木㱔肥所常務取締役, 多木 英勝氏ならびに同社矿究所長広田元太郎氏に深謝の意を表する。

\title{
閃光分解法による炭化水素の燃焼の研 究
}

低級炭化水素の誘導期閒, 懪発限界と発光スペクトル†

(罗和 35 年 12 月 8 日受理)

\section{高橋 猛夫・吉田、栄一・増子 昭 義*}

閃光分解法を利用して少量の二酸化窒素を添加したェチレン, ェタン括よびメタンと酸素との混合物を爆発させ, 前に 得たアセチレンの結果と比較した。誘導期間や爆発限界についてはこれら低級炭化水素の間で大きな差がある。

また二, 三の然料濃度について測定位置を変化した場合の $\mathrm{OH}, \mathrm{CN}$ 強度を光電的な方法で測定し, 同時に爆発王をピ エゾ型圧力計で測定した。このような同時测定によって Thrush.らが報告している爆こう波および反射衝撃波が応管 内を公播することを確めた。

\section{1 緒 : 言}

前報1,2)において，われわれはピエゾ型圧力計による爆発圧の 测定 ${ }^{3)}$ ，分解反応生成物のガスクロマト分析等から，アセチレン 扣よび水素の誘導期間や爆発限界について二酸化窒素の量, 燃料 濃度, 圧力, 閃光エネルギーを変えた場合の関係を系統的に求め たが，本報ではエチレン，エタン扣よびメタンについて同様の実 騟を行ない, これら低級炭化水素を比較検討した。

さらに，動圧力の測定から誘導期間を求める場合の爆発圧の時 間遅れ，むるいは测定位置を変化した場合の爆発圧や，発光スペ クトルの消長の時間関係等を明らかにする目的で，主としててセ チレンについて $\mathrm{OH}, \mathrm{CN}$ 遊離基の発光と動圧力との同時測定を 行なった結果についても報告する。

\section{2 実験装置および方法}

誘導期間，爆発限界の測定装置および方法は前報1)とほとんど 同じである。すなわち，今までど拈りピエゾ型圧力計による爆発 王の測定から誘導期間を求め，これに爆発前後の静圧の測定，分

†本報を「炭化水素の燃焼の研究（第 3 報）」とする.

* 日本石油株式会社中央技術研究所：涉浜市神奈川区宝町.

1) 高橋, 吉田, 增子, 工化 63,2130 (1960).

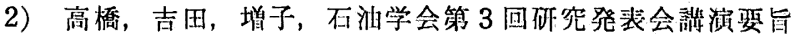
p. 75 (1960).

3）高橋, 吉田, 增子, 工华 63，1364 (1960),
解反応生成物のガスクロマト分析を併用して爆発の有無を確認し た。さらにガスクロマト分析では多少時間がかかるので，一部は 日立自記分光光度計汇よる $220 \sim 230 \mathrm{~m} \mu$ の領域の紫外吸収スペ クトルを测定し，二酸化窒素の減少，一酸化窒素の生成から爆発 の有無を判定した。

実験の再現性についても前報1)で詳細に述べたが，くり返しの 再現性よりも長期間にわたって, 同一条件を保つことが困難にな る。このため, 各炭化水素については時々量論比混合試料を調合 し，爆発限界を測定してその間に変化があるかどうかをしらべ， 必要があれば閃光放電管, 反応管の洗浄あるいは反応管ヶース内 面に酸化マグネシウムを蒸着し直した。また各炭化水素相互の関 係については同一㭙に量論比混合試料を調合して, 同一条件で実 験し，直接比較を行なった。

次に遊離基の発光スペクトルの測定には光電的な方法4)を用い た。図 1 に示すように，反応管の軸方向およびこれと垂直方向か らの光を島津 QL-170 型分光写真器 るるいは干涉フィルターを 通して光電子増倍管 1 P 28 に受け，その出力をカソード・フォ ロアー1段增幅して岩崎通信機 5153 型二電子銃シンクロスコー プで测定した。分光器の場合は乾板の位置に移動自由な簡単なス リットを取付け, 3064 Åの OH 帯頭, あるいは $3884 \AA$ の CN 带頭の位置に調整した。干涉フィルターでは短波長のるのがえら

4) R. G. W. Norrish, G. Porter, B. A. Thrush, "Fifth Symposium on Combustion" p. 651 (1955) Reinhold. 


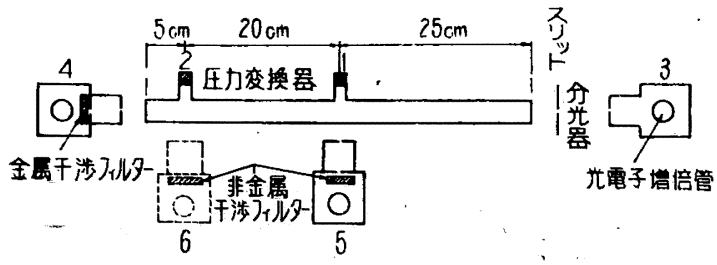

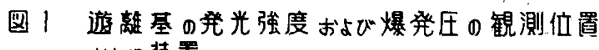
およひ漖置

れなかったので, CN のみを测定したが, 使用した湘南光膜製金属 扣よび非金属干涉フィルターの特性は，それぞれ $\lambda_{\max }: 392 \mathrm{~m} \mu$, $T_{\max }: 27.5 \%, \Delta \lambda_{1 / 2}: 12 \mathrm{~m} \mu$ および $\lambda_{\max }: 421 \mathrm{~m} \mu, T_{\max }:$ $54 \%, \Delta \lambda_{1 / 2}: 7 \mathrm{~m} \mu$ である。

図 1 には，また爆発圧の観測位置も示しており，これらのらち

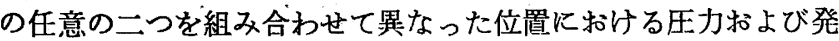
光スペクトルを同時記録した。

用いた試料のうち，エタンは Phillips 社製標準試料で，純度 99.75\%，エチレン执よびメタンは Matheson 社製で，純度はそ れぞれ $99.5 \%$ ，99\% であり，その他はいずれる前報と同一であ る。

\section{3 実験結果および考察}

\section{1 誘導期間, 爆発限界}

エチレンー酸素系試料について，10\% の二酸化窒素を添加した 全压 $30 \mathrm{mmHg}$ の量諭比混合試料 (モル比 1:3) の桥導期間と, 閃光エネルギーとの関係を図 2 に示す。高い周波数を含む爆発圧 の測定ではピェゾ型圧力計の固有振動数等のために大ささや波形 に問題はあるが; 一応測定される爆発圧はアセチレン同様に高い の飞、この方法によって全圧 $10 \mathrm{mmHg}$ 程度までの試料の短い誘 導期間を比較的容易に求めることができる。

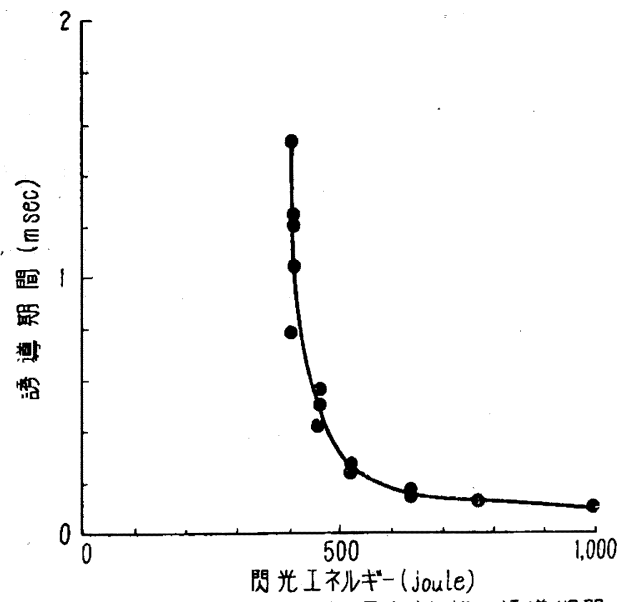

图2工开乡酸素量論比混合試料の誘道期間 $\left(\mathrm{NO}_{2}: 10 \%\right.$ ，全压. $\left.30 \mathrm{mmHg}\right)$

因 3 は同じ試料について，爆発限界に対する全圧と閃光エネル ギーとの関係，図4 は燃料濃度を変えた場合の爆発限界を示す。 爆発の有血の判定もアセチレンと同様で，高試料圧では爆発圧の 湘定が有效であるが，低試料圧の場合に量論比およびこれより薄 い試纬については，分解生成物のガスクロマト分析，また量椧比 よりも濃い試料では爆発すれば圧力が相当增加するので, 閃光前 後の静圧の測定で行なった。

また一部は光路長さ $10 \mathrm{~cm}$ のガスセルを用いて，220〜230 $\mathrm{m} \mu$

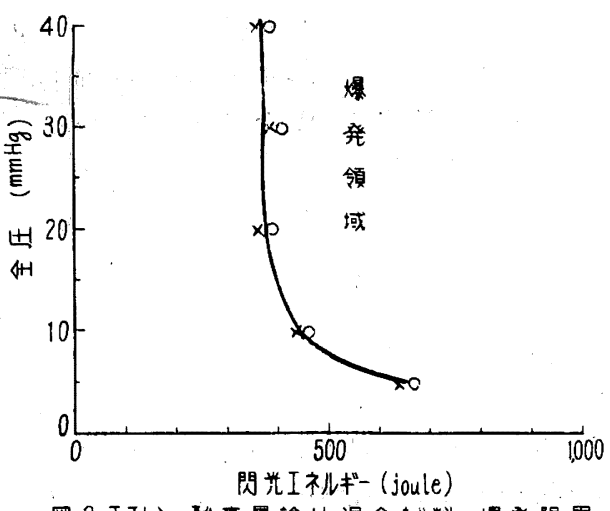

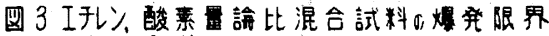
$\left(\mathrm{NO}_{2}: 10 \%\right)$

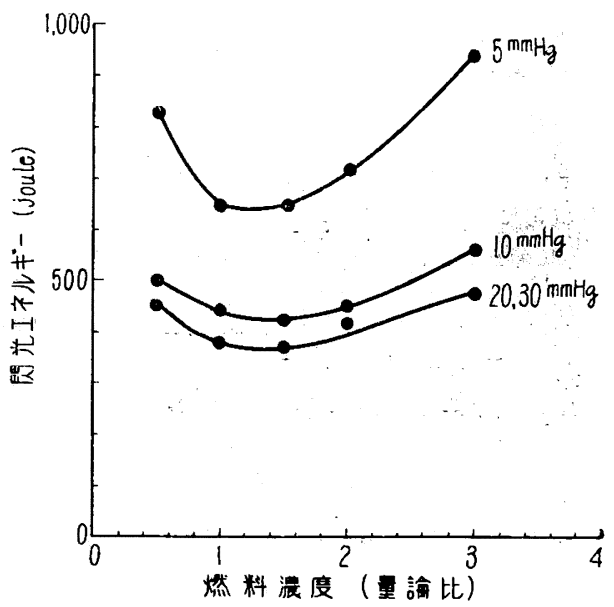

圆 4 I孔り酸素混合試料の塂発限界 $\left(\mathrm{NO}_{2}: 10 \%\right)$

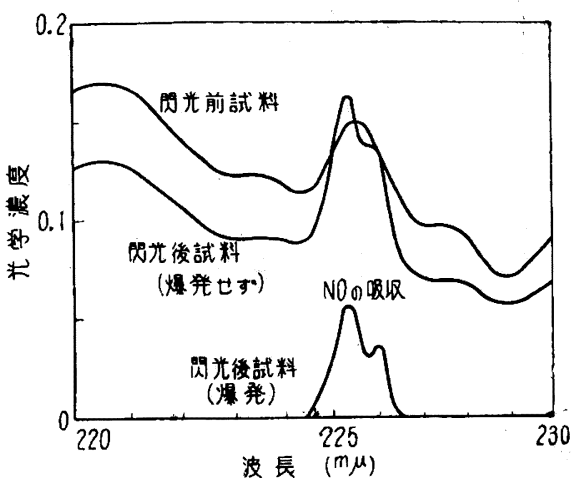

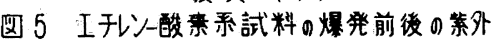
吸収入ペ止儿測定䊅果の一例

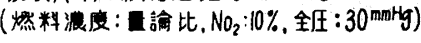

の紫外吸収スペクトルを測定し, 二酸化窒素の減少, 一酸化空素 の生成から爆発の有無を判定した。図 5 は, 全圧 $30 \mathrm{mmHg}$ の 量論比試料での結果の一例であり，紫外セルに採取された試料圧 は, 反応管と紫外セル, 圧力計, 学管の容積比で約半分に低下す るが，爆発しない㭙でも閃光の大きさに従って一部の二酸化空素 が光分解して，一酸化空素に変わっている点が，明確に認められ た。このほかのものは近紫外領域に邀当な吸収がないので，分析 できないが，ガスクロマトによればアセチレンの場合のよ5に然 料, 酸素, 一酸化炭素, 炭酸ガスの量が爆発限界前後の閃光エネ ルギーで判然とわかれた。

エタンおよびメタンと酸素との混合試料では，爆発に必要な閃 
光エネルギーがアセチレンの場合より相当大きく5)，また爆発圧 が低いので，20\%の二酸化窒素を添加した試料について誘導期 間を測定した。因 6 は誘導期間を求めるために行なったメタンに ついての爆発圧の測定例であり，図７にはエタンおよびメタンの 量論比混合試料（モル比はそ杋ぞれ $1: 3.5$ 拈よび 1:2）の誘 噂期問と閃光エネルギーとの関係を示す。

图8はエタンおよびメタンについて然料浱度を変えた場合の爆 発限界の 測定結果で，比較のために 相当するアセチレン 和よび

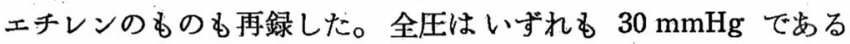
が, 爆発限界付近では爆発圧が低いので, 分解生成物のガスクロ マト分析と, 閃光前後の静圧の測定を佯用して爆発の有無を確め た。

以上の結果から，誘導期間については閃光エネルギーの大きい ところでは非常に短く, 然料の種類, 然料濃度等による差が認め られないが, 閃光エネルギーが小さく, 爆発限界に近つくにつれ

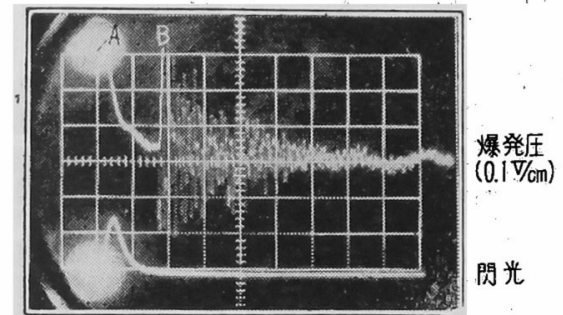

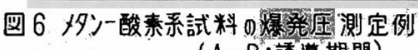

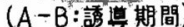

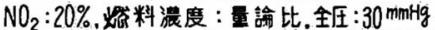

閔光工祃ギー: 640 joule, 绵引時間: $100 \mathrm{\mu sec} / \mathrm{m}$

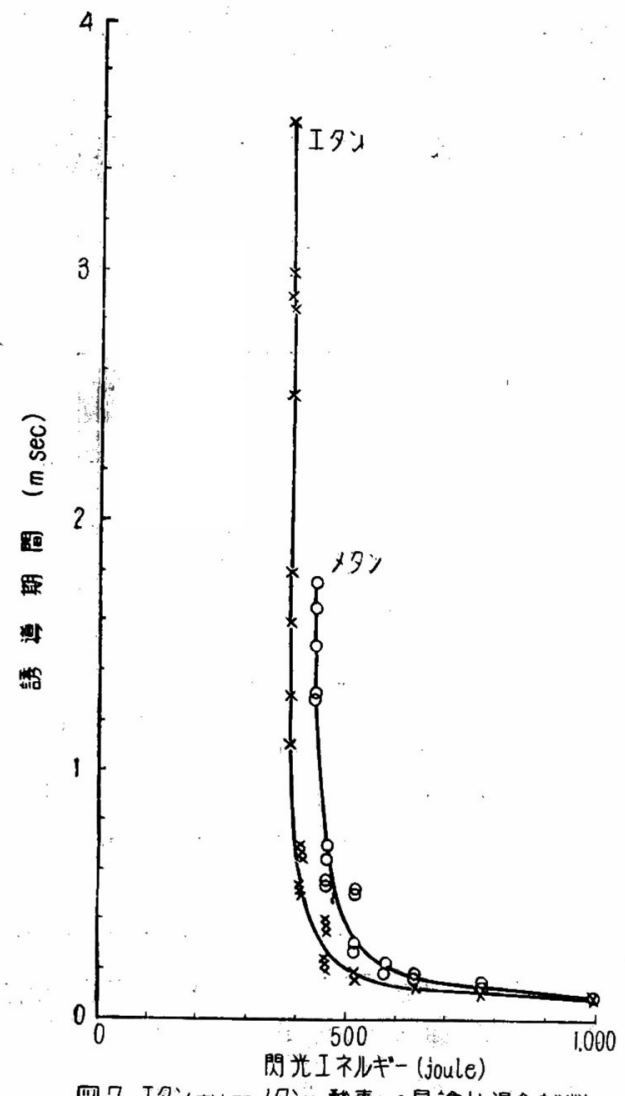

圆 7 Iタンおよびメタンと酸素との星論比混合試料の 誘導期間 $\left(\mathrm{NO}_{2}: 20 \%\right.$, 全压: $\left.30^{\mathrm{m} m \mathrm{H} H \mathrm{H}}\right)$

5). R. G. W. Norrish, G. Porter, B. A. Thrush, Proc. Roy. Soc. A 227, 423 (1955).

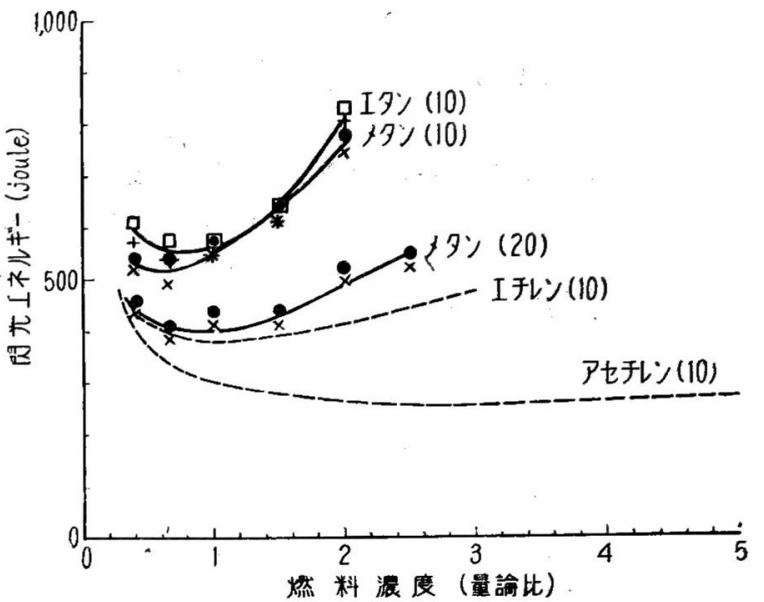

图 8 低粐岸化水索の爆発限界の比㜞 (全压: $30 \mathrm{mmHg}$, 括弧内数字 $1 \mathrm{NO} \%$ 示す)

て急激に增加し，それらの影響が大きくあらわれるという前報の 結果を再確認した。誘導期間の短い所で差が認められない原因に ついては; 閃光の持続時間が比校的長く, 爆発圧の伝ぱ遅れ等に も関係すると考えられるので，さらに持続時間の短い閃光放電管 を用いて検討する必要がある。誘導期間が長い所では爆発限界に 対する接近の程度でだいたい決まるため，同じ条件ではアセチレ ン, エチレン, エダン (メタンはエタンと変らない) の順に誘導 期間は長くなるが, 然料濃度に関しては極小になる濃度が存在す ることになる。

爆発に必要な最低の閃光エネルギーもアセチレン, エチレン, エタン（メタンはェタンと変らない）の順に増加し，とくに然料 濃度の濃い場合に大きな差があり，爆発領域も狭くなる。アセチ レンでは全圧が高い場合には，量論比よりもかなり然料の濃い所 に最低值があり, 全圧が低下寸るにつれて, 最低值は量論比付近 に移る ${ }^{1,2)} 。$ エチンンの場合にも，それはどはっきりはしないが, 同じ傾向のようであり，またメタンについては，最小点火エネル ギーの結果6) 同様に, 最低值は量論比より薄い然料で起こってい る。

誘導期間, 爆発限界はもちろん使用する装置, 方法および実験 条件で非常に異なるすのであり，このよ5な低圧の誘導期間の短 い測定例は非常に少なく, 従来の結果との比較は一般に困難であ る。

\section{2 遊離基の発光スペクトルと爆発圧}

10\% の二酸化至素を添加した燃料濃度 2.5 および 3.5 (量論 比）のアセチレンー酸素系試料について，図 1 に示した位置に和 ける遊離基の発光スペクトル，扣よび爆発圧を測定した結果を図 9 (a) （e）に示す。同図中左右の対応するすのは同一条件で, 然料濃度のみ変えて実験しているので, 縦軸の高さとその時のシ ンクロスマープの感度比から強度比校が可能である。

ます゚反応管の中心軸方向からの $\mathrm{OH}$ 遊離基の発光強度、およ び持続時間は然料濃度 2.5 のほ 5 が 3.5 の場合よりる大である が (図 9-a)，CN 遊離基では逆である（図 9-b)。なお $\mathrm{CN}$ 遊 離基の消長については（図 9-b) のフィルターを用いた結果と, 3 の位置で分光器を用いた測定結果がほとんど同じであり，OH

6) M. V.Blanc, P.G.Guest, G. von Elbe, B. Lewis, "Third Symposium on Combusion" p. 363 (1949) Williams and Wilkịnș. 
と $\mathrm{CN}$ の强度比較では燃料濃度 2.5 の場合でも $\mathrm{OH}$ の ほうが弱いので， OH の場合には光䉓子增倍管の印加電 圧を上げる必要がある。

次に反応管に 垂直方向からの $\mathrm{CN}$ 遊離基の持続時間 は，中心軸方向から測定されるものにくらべてかなり短 く(図 9-b, - c , - d ), 強度も弱い。また $\mathrm{CN}$ 遊離基の 持続時間の長い燃料濃度 3.5 の場合には，発光強度飞第 2 の山が認められ，中块で観测した場合の添うが二つの 山の間隔が広い。

観測位置による発光，爆発圧の時間関係についてい, 誘導期間の測定に用いた反応管中央に和ける爆発圧の立 ち上がりの時間を規準にすると，発光の最大になる時間 が $\mathrm{OH}$ では多少遅れ，CN ではだいたいこれと同じか， わずかに速い。また管端における爆発圧は（図 9-e）に 示すよ5に, 中央のものよりさらに数 $10 \mu \mathrm{sec}$ 遅れ, この遅れは, 閃光エネルギーの增加とともに多少短くな る。

以上の結果を説明するには, Thrush が反応の均一性 そついての報告》で述べているように, 反応管内に衝撃 波の発生, 云ばを考党る必要がある。もっとも, 衙撃波 による数 $\mu$ sec の鋭い発光の山は, 図 10 に示すよ5に 予備実験のとき一時観測されたが, 図 9 からは検出でき ず，その原因は不明である。しかし，圧力波形の急峻な 立ち上がり, 固有振動数の高いピエゾ型圧力計でもな拉 圧力が上下に振動的に観測されることから, 衝撃波の発 生は十分に考觉らることである。

吸収スペクトルによる OH，CN 等の消長については Norrish らの詳細な研究8)があり, 二酸化窒素のため, アセチレン-酸素の等モル混合試料（現在の 2.5 の濃度 に相当）上り，多少燃料の濃いところで $\mathrm{OH}$ の吸収は 急激に弱くなり, 炭素を含む遊離基の吸収が強くなると 述べている。四 9-a, -b でも然料濃度に関しては同様 の傾向があるが, 発光スペクトルの場合には励起状態関係し, 温度の影響を強く受けるので，図 9-c，-d の垂直方向からの迶 離基の持続時間が短いことは爆ご波の伝ぱによる温度上界から 説明でき，また燃料濃度 3.5 の場合の第 2 の山は反射衝繋波とし て説明される。

全圧 $30 \mathrm{mmHg}$ の量論比混合試料のアセチレン, エチレン, エタンおよびメタンについて， $500 \mu \mathrm{sec}$ 程度の湦れで（閃光エ ネルギーはアセチレン，エチレンの順に高くなる）OH 遊離基の 発光強度を比較した結果, 発光強度はこの順に低下し, だいたい 前のものの 1/2 1/3 になり，水素ではさらに低い。

Norrish $5^{5)}$ は $\mathrm{OH}$ 遊離基の吸収スペクトル強度はこれらの 炭化水素でだいたい同じであるが，Cを含む遊離基の四収強度は， アセチレン，エチレンと順に弱くなる結果を得ており，衝撃波に

7) B. A. Thrush, Proc. Roy. Soc. A 233, 147 (1955).

8) R.G.W. Norrish, G. Porter, B.A.Thrush, Proc. Poy. Soc. A 216, 165 (1953)；高橋，燃汾誌 39, 81 (1960).

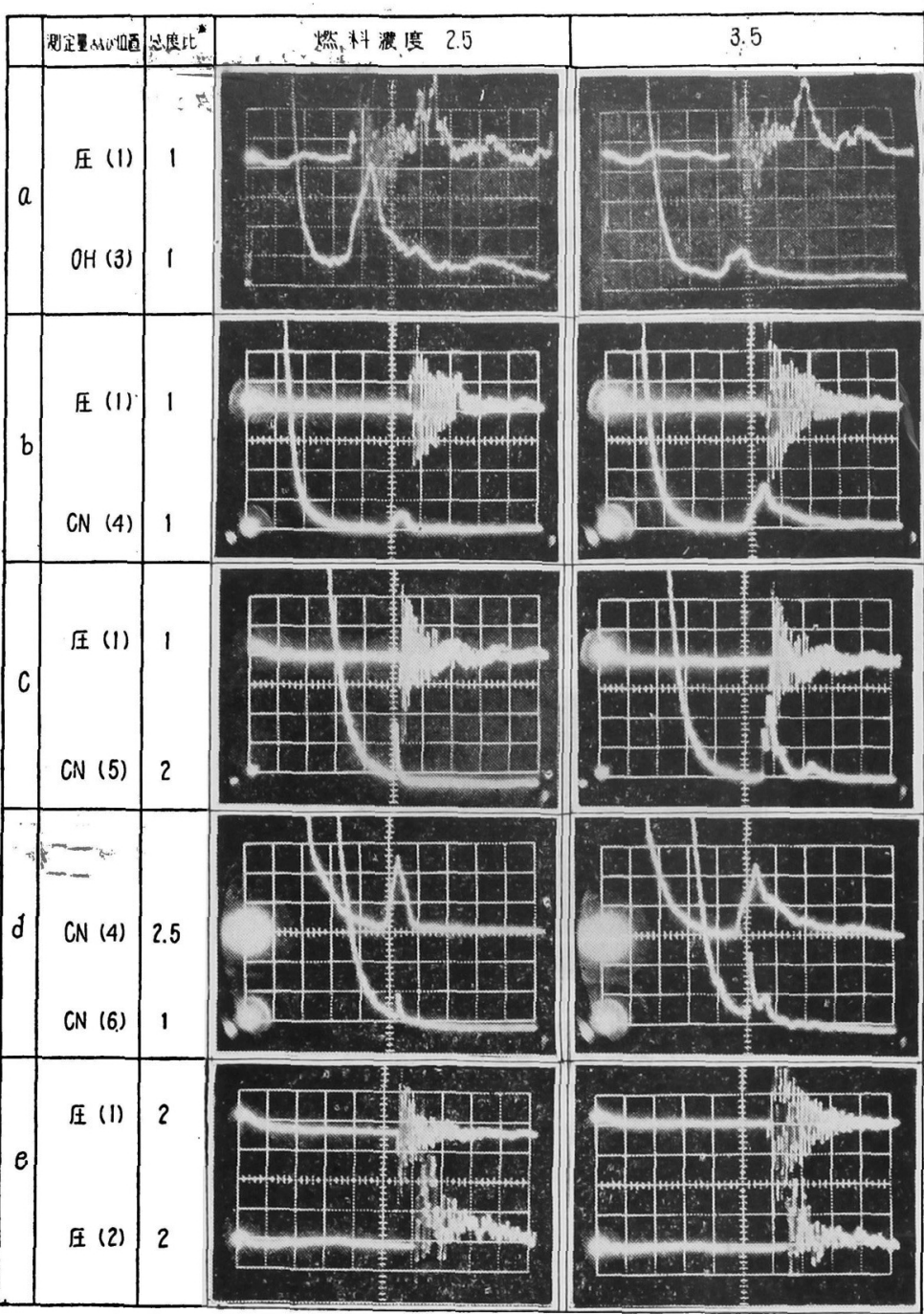

四 9 アセチレンー酸素系試料の惯発王および遊離基の兴光スソ゚クトル 測定䊅果 ( $\mathrm{NG}_{2}: 10 \%$, 全庄: $30^{\mathrm{mmHg}}$, 㛿引時間: $\left.100 \mu \mathrm{sec} / \mathrm{cm}\right)$

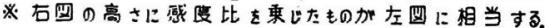

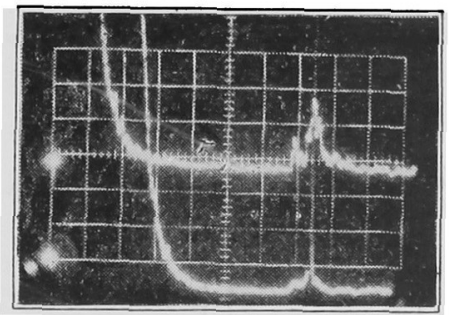

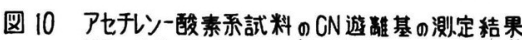
$\mathrm{NO}_{2}: 10 \%$, 燎料浱度 (量論比): 18 , 全圧 : $30 \mathrm{~mm}$

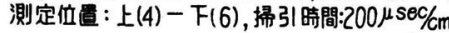

よる爆発圧がエタン，メタン括よ゙水素で低い原因は，このよう な発光スペクトル強度に影響をもつ瞬間的な温度と関係があるも のと思われる。

本研究について貴重な御教示を賜わった東大航空研究所山崎毅 六教授, 東大工学部疋田強教授ならびに当所熊谷良一所長, 福島 健重課長に深甚なる感謝の意を裴する。 